\title{
Potential of Natural Resources in Renewable EnergyDevelopment in Ngawi District, Ngawi Regency
}

\author{
Ita Mardiani Zain ${ }^{1, *}$, Wiwik Sri Utami ${ }^{2}$ \\ ${ }^{1,2}$ Geography Education Department Universitas Negeri Surabaya, Surabaya, Indonesia \\ *Corresponding author.Email: itamardiani@unesa.ac.id
}

\begin{abstract}
The new alternative renewable energy that emerges is highly expected to be a new source of energy for the people in Ngawi Regency, so that it can grow all existing potential both in terms of the community's economy and other aspects of life. The purpose of this study is to explore and map the Potential of Natural Resources in the Ngawi District Ngawi Regency based on maps to get data that can be aligned with the needs of new renewable energy sources that might be applicable. The survey was conducted on a primary and secondary basis. The method used is direct observation technique, indirect observation technique, and indirect communication technique. Data analysis in order to produce optimal analysis validation in the process of preparing development programs. Potential development of new and renewable natural resources in Ngawi District, Ngawi Regency includes the development of hydro, solar, bioethanol and biogas energy sources
\end{abstract}

Keywords: Potential, Natural resources, Renewable energy.

\section{INTRODUCTION}

Ngawi Regency is located in the western region of East Java Province which borders directly with Central Java Province. The area of Ngawi Regency is $1,298.58 \mathrm{~km} 2$, of which around 40 percent is paddy fields. Administratively the area is divided into 19 subdistricts and 217 villages, of which

4 of the 217 villages are kelurahans. Ngawi Regency is geographically located at $7^{\circ} 21^{\prime}-7^{\circ}$ $31^{\prime}$ South Latitude and $110^{\circ} 10^{\prime}-111^{\circ} 40^{\prime}$ East Longitude. The topography of this region is in the form of plateaus and flat land. Noted 4 subdistricts are located in the highlands of Sine, Ngrambe, Jogorogo and Kendal which are located at the foot of Mount Lawu.

The geographical location of Ngawi Regency which is on the slopes and valleys of Mount Lawu allows a lot of natural potential contained in one of the Districts. Alternative energy must be created, raised and new renewable energy in order to maintain the survival of the community. Examples of studies exploring the potential of natural resources in Ngawi District can be aligned with the needs of new renewable energy that is very likely to be produced by the community themselves. The many potential natural resources have not yet been explored, outlined and documented clearly especially in the form of maps in existing documents. The new alternative renewable energy that emerges is highly expected to be a new source of energy for the people in Ngawi Regency, so that it can growall existing potential both in terms of the community's economy and other aspects of life. The purpose of this study isto explore and map the potential of natural resources in NgawiDistrict based on maps to obtain data that can be harmonized with the needs of new renewable energy sources that might be applicable.

Borawski used descriptive and statistical methods to describe the changes in bioenergydevelopment in the European Union (EU). The biggest share of biofuels and renewable waste can be seen in Latvia (31.2\%), Finland (26.7\%) and Sweden (24.8\%). The highest percentage of wind energy in 2015 was found in: Denmark (7.2\%), Portugal (4.3\%), Ireland $(4.0 \%)$ and Spain (3.5\%). The highest share of solarenergy in 2015 was found in Cyprus (3.5\%), Spain (2.6\%) and Greece $(2.2 \%)$. The highest contribution of geothermal energy was found in 2015 in Italy (3.5\%), Portugal $(0.8 \%)$ and Slovenia $(0,7 \%)$. Hydropowerwas the biggest in 2015 in Sweden $(14.2 \%)$, Austria (9.6\%) and Slovenia (5.0\%). 
The highest coefficients ofvariation of the share of electricity from renewable energy sources were found in the years 2004- 2017 inMalta (140.3\%), Cyprus (101.1\%) and United Kingdom (71.9\%). In addition, the highest coefficients of variation of share of renewable energy sources in heating and cooling in the years 2004-2017 were found in Malta (72.4\%), United Kingdom (69.81\%) and Hungary (44.91\%). Moreover, the highest coefficients of variation of share of renewableenergy sources in transport in the years $2004 \mathrm{e} 2017$ werefound in Finland (113.78\%), Malta (115.52\%) and Belgium $(96.53 \%)$. The biggest producers of ethanol and biodiesel in EU were Germany, France and Poland

\section{METHODS}

The survey was conducted on a primary and secondary basis. The primary survey is for a checklist and table of contents, while the secondary survey takes data from related institutions such as local regulations, laws, population and natural resources. The method used is direct observation technique, indirect observation technique, and indirect communication technique.

Data analysis to produce optimal analysis validation in the process of developing development programs uses several methods and models, namely the characteristics of natural resources, the potential and problems of natural resources, and the formulation of the development of natural resources for renewable energy

\section{RESULTS AND DISCUSSION}

\subsection{Result}

Potential development of new renewable natural resources in Ngawi District includes the development of hydropower, solar energy, bioethanol and biogas energy sources. The following is a detail of each energy source and its location mapping

Table 1 Energy Type, Potential Natural Resources Information

\begin{tabular}{|l|l|l|l|}
\hline \multicolumn{1}{|c|}{ No. } & \multicolumn{1}{|c|}{$\begin{array}{c}\text { Energy } \\
\text { Type }\end{array}$} & $\begin{array}{l}\text { Potential Natural } \\
\text { Resources }\end{array}$ & \multicolumn{1}{c|}{ Information } \\
\hline 1 & Hidro Power & Water Springs (1 poin) & Using Pikohydro atau Microhydro \\
\hline 2 & Solar Power & $\begin{array}{l}\text { Sunlight on the district's } \\
\text { main } \\
\text { Streets }\end{array}$ & Using solar panel for PJU atau Traffic light \\
\hline 3 & Biofuel-Biogas & Beef cattle & $\begin{array}{l}\text { Accommodating and processing livestock manure to } \\
\text { become a source of energy }\end{array}$ \\
\hline 4 & $\begin{array}{l}\text { Biofuel- } \\
\text { Bioetanol }\end{array}$ & Sugar cane plant & Fermenting sugar cane into oil as a fuel sources \\
\hline
\end{tabular}

\subsection{Discussion}

\subsubsection{Hidro Power}

Analysis of the potential of natural resources hydropower can be an alternative energy power plant. The scale of existing water resources will affect the amount of electrical energy produced. According to [1] Micro-hydro power plant is a type of renewable power plant that is environment friendly, easy to be operated and low operation Cost. Power plants based on electrical energy output are divided into 4 (four), including picohydro $(5 \mathrm{~kW})$, micro hydro $(5 \mathrm{~kW}-100 \mathrm{~kW})$, minihidro (101kW-1MW) and large dam / DAM / hydro (> $100 \mathrm{MW}$ ). Water resources in Ngawi Regency consist of dams, embung and kedung/ check dams. To make this renewable energy a water resource, several requirements are needed. Ngawi Regency has 153 springs (Ngawi Regency in Figure 2018) which is spread in Ngawi District 1 point. Small scale power plants such as Pico Hydro, Mini Hydro and Micro Hydro, the community or certain groups can utilize this alternative energysource.

According to [1] The power plant will use 25.2 $\mathrm{kW}$ of the hydraulic potency based on flow rate 0.3 $\mathrm{m} 3 / \mathrm{s}$ and head height $8.6 \mathrm{~m}$. For larger-scale power plants to obtain greater power, better financial support from local, provincial and central government is needed. Using springs can use micro hydro or piko hydro 


\subsubsection{Solar Power}

Solar energy can be applied anywhere. This is very useful for remote areas without access to other electricity sources. Solar energy is an environmentally friendly energy source and cheaper is another advantage of the utilization of solar energy. Solar energy has the least impact on the environment compared to other energy sources. Solar energy does not produce greenhouse gases, does not pollute water, requires little water for maintenance and does not cause noise.

Utilizing sunlight as an energy source is considered very environmentally friendly. For example, 5,000 MW of energy generated from PLTS, when converted will be equivalent to planting 18,124 trees, saving 1.5 million diesel fuel for PLTD and preventing $\mathrm{CO} 2$ emissions from PLTD of 3.6 million tons. Solar Craft, every $1000 \mathrm{kWh}$, solar panels can reduce emissions of nearly 8 pounds of sulfur dioxide, 5 pounds of nitrogen oxide and 1,400 carbon dioxide. According to [2] A number of solar-based projects in Northern Chile remain in thepipeline and the country recently announced plans to developa 1865 mile transmission line to aid the transfer of solar power to other parts of the country.

In addition to solar power, solar panels can be applied on a smaller scale. Such as households, small scale industries or the use of solar (photovoltaic) panels to fill electricity in public street lighting (PJU).

Locations for the utilization of solar energy in Ngawi District can use open space exposed to sunlight throughout theday.Accrording to [3] The solar energy source was modelled as a concentric solar dish collector, considering a receiverlocated at the focal point and designed to absorb the maximum possible of the solar radiation. Utilization of solar panels as a source of PJU energy, the main roads in Ngawi District can be used as the right location.

\subsubsection{Biofuel-biogas}

Biofuels provide solutions so that the natural resources used can be reused. Biofuel is divided into three bioethanol, biodiesel and biogas, the use of biofuels in Ngawi District has the potential to be developed. According to [4] Biofuels have alarge share in the production of energy from renewable sources and are friendly with the environment. The usage of biofuels does not produce substances hazardous to theenvironment and it does not have negative impacts on engines. According to [5] Biofuels, fuels from living organisms, provide environmental benefits, since their use leads to a decrease in the harmful emissions of $\mathrm{CO} 2$ and hydrocarbons and, to the elimination of $\mathrm{SOx}$ emissions, with a consequent decrease in the greenhouse effects.

The characteristics of natural resources based on the economic sector in the Ngawi sub-district of the agricultural sector have the potential to be used as biofuel energy with the type of bioethanol. According to [4] First generation biofuels can be produced from rapeseed, grains, beetroot, and potatoes. These biofuels are made from oil-based plants, starch crops and sugar.

Bioethanol is alcohol derived from plants, such as wheat, sugar cane, corn, cassava, sweet potatoes, fruits, to vegetable waste. According to [6] as algae-based biofuels are advanced ones, not competing in the use of land against any other crop. Alcohol obtained from plants must pass the fermentation process first. According to [7] small scale ethanol production has higher potential in terms of energy efficiency, renewability, and sustainability. Based on the results of the LQ analysis of the agricultural sector for the internal scale ofNgawi District produces commodities of rice, corn, soybeans, soil braids and cassava which are quite productive and not focused on one commodity.

The livestock sector has the potential as a source of renewable energy in the form of biogas. Biogas is a gas produced by anaerobic activity or fermentation of organic materials including; human and animal waste, domestic (household) waste, biodegradable waste or any biodegradable organic waste in anaerobic conditions. The main ingredients in biogas are methane and carbon dioxide. Livestock waste if handled carelessly, it will pollute the environment.

Biogas basically uses methane gas produced by animals to be processed into gas fuel. Accroding to [8] that biogas and biomethane reduce dry biomass consumption by up to $16 \%$ when used for power, heat or industrial sectors. If biogas feedstock is free for energy purposes, this brings significant energy system cost reductions, but when the energy sector pays for the biogas feedstock, then savings are lower, in which case biogas and biomethane still reduce the energy system costs for use in power, heat or industrial sectors. 
Specific volume and time period to accommodate biogas so that it can be a source of fuel. All types of animals produce manure containing methane gas, but the amount that produces will affect whether or not the fuel source appears. Biogas can be a source of gas fuel and can also be used to produce electricity.

The livestock sector in Ngawi Regency consists of large livestock to poultry. Waste from the livestock sector has the potential to become a renewable energy source. Based on the results of LQ analysis of the livestock sector for the internal scale of Ngawi Regency, it can be seen that in some districts the area produces commodities that are quite productive and are not focused on one commodity, namely cattle, buffalo, horses, goats and sheep.

The plantation sector in Ngawi Regency includes coconut, sugar cane, tobacco, rubber, tea, cocoa plantations, etc. Sugarcane, tobacco, and cocoa can be used as bioethanol, while coconut can be used as biodiesel. Based on the LQ analysis of the plantation sector for the internal scale of Ngawi Subdistrict, the production of coconut and sugar cane is quite productive and not focused on one commodity

\subsubsection{SWOT Development Analysis}

SWOT analysis is one of the analytical techniques used in interpreting the planning area, especially in very complex conditions where internal and external factors play an equally important role. This analysis aims to determine the potential and problems that exist in an area of planning and how these problems can be resolved with the existing potential. Thisanalysis considers anticipation in the future. Based on the analysis done above, the development strategies that can be carried out for the development of natural resources as new renewable energy for biofuels include:

1. Development of bioethanol manufacturing centers utilizing plants with abundant production, such as corn, sugar cane, cocoa

2. Development of a biodiesel manufacturing center that uses coconut plants

3. Adding the installation point of waste water management from livestock waste on farms on a large scale to be usedas a source of biogas energy

4. Evaluate biogas reactors that have already been operated

5. Making the Selopuro landfill study as a biogas energy source

6. Counseling on the important and long-term role of biogas inenergy procurement

7. Dissemination to people with an interest in commodity crops for biodiesel, bioethanol and biogas

8. Utilization of farmer groups for the supervision of wastewater treatment plants and biogas reactors

9. Increasing the role of the community in development tobring up a sense of belonging

Table 2 SWOT Analysis

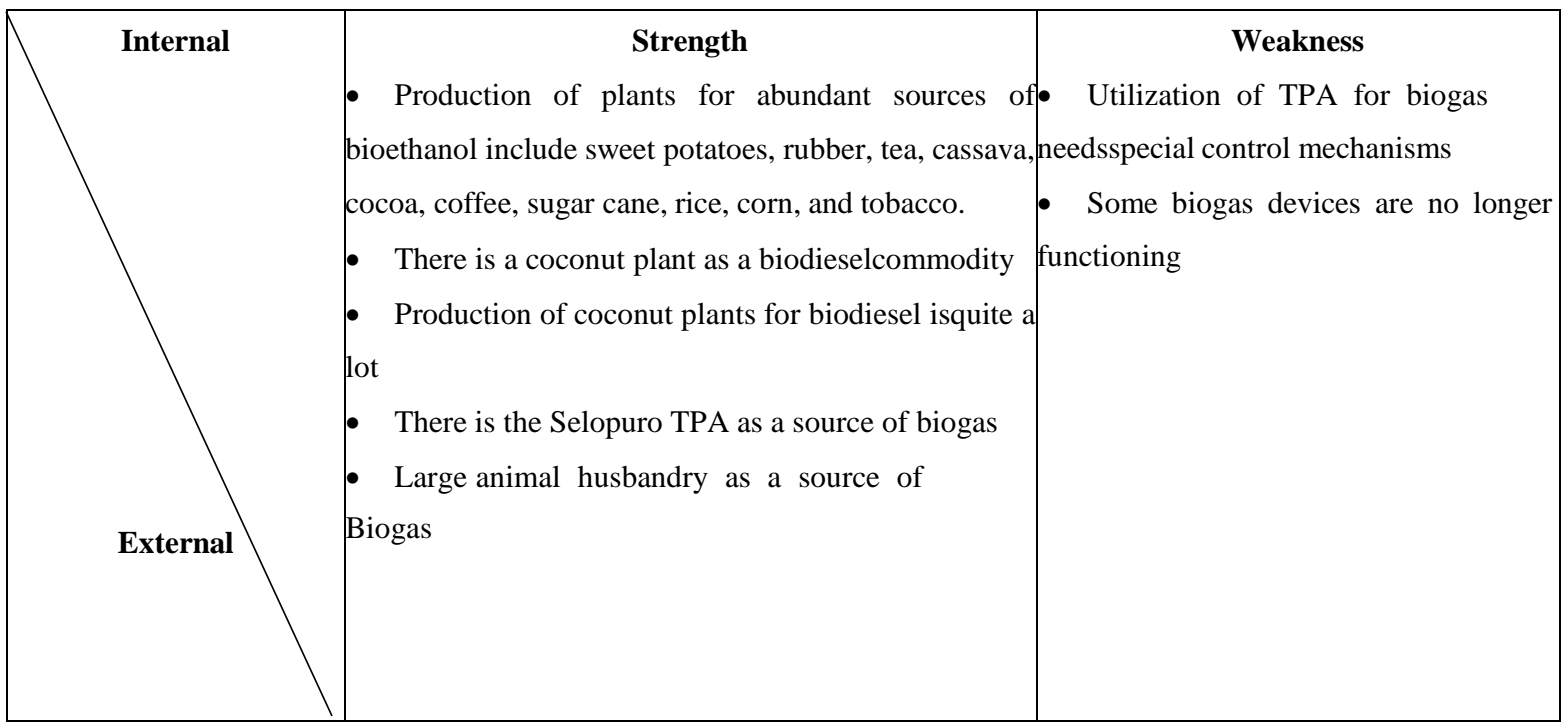




\begin{tabular}{|c|c|c|}
\hline $\begin{array}{l}\text { Opportunity } \\
\text { Types of plants as a } \\
\text { source ofbioethanol vary } \\
\square \text { There are functioning } \\
\text { biogas reactor } \\
\text { points }\end{array}$ & $\begin{array}{l}\text { - Development of bioethanol manufacturing centers } \\
\text { utilizing plants with abundant production, such as corn, } \\
\text { sugar cane, cocoa } \\
\text { - Development of a biodiesel manufacturing center } \\
\text { that uses coconut plants } \\
\text { - Adding points for the installation of wastewater } \\
\text { management from livestock waste on farms on a large } \\
\text { scale to be usedas a source of biogas energy } \\
\text { Evaluate biogas reactors that have already } \\
\text { been operated }\end{array}$ & $\begin{array}{l}\text { Making the Selopuro TPA study a } \\
\text { source of biogas energy } \\
\text { Counseling about the important and } \\
\text { procurement }\end{array}$ \\
\hline $\begin{array}{l}\text { Threat } \\
\text { Willingness from the } \\
\text { community tocreate and } \\
\text { participation is stilllacking } \\
\text { Lack of ownership } \\
\text { of government } \\
\text { support tools }\end{array}$ & $\begin{array}{l}\text { Dissemination to communities with aninterest in e } \\
\text { commodity crops for biodiesel,bioethanol and biogas }\end{array}$ & $\begin{array}{l}\text { Utilization of farmer groups for } \\
\text { supervision of water and waste } \\
\text { management installations and biogas } \\
\text { reactors } \\
\text { Increasing the role of the community } \\
\text { in development to create a sense of } \\
\text { ownership }\end{array}$ \\
\hline
\end{tabular}

\subsubsection{Power Solar}

SWOT analysis for solar power can be seen below:

Table 3 SWOT analysis for solar power

\begin{tabular}{|c|c|c|}
\hline Eksternal & $\begin{array}{l}\text { Strength } \\
\text { - Ngawi is a tropical region which is exposedto } \\
\text { the sun throughout the year }\end{array}$ & $\begin{array}{l}\text { Weakness } \\
\text { - Solar panels are quite } \\
\text { expensive } \\
\text { - Not applicable on a } \\
\text { large scale (Solar } \\
\text { Power Plants) }\end{array}$ \\
\hline $\begin{array}{l}\text { Opportunity } \\
\text { - The area that is exposed toenough } \\
\text { sun }\end{array}$ & $\begin{array}{l}\text { - Optimize the area of the sun-exposed areafor } \\
\text { solar panel locations }\end{array}$ & $\begin{array}{l}\text { - The use of solar } \\
\text { panels on a small } \\
\text { scale, for example } \\
\text { PJU (Public Street } \\
\text { Lighting) }\end{array}$ \\
\hline $\begin{array}{l}\text { Threat } \\
\text { - Need community support } \\
\text { maintain public facilities }\end{array}$ & $\begin{array}{l}\text { - Inviting people to use renewable energy in } \\
\text { the form of solar panels to meet their daily } \\
\text { energy needs }\end{array}$ & $\begin{array}{l}\text { - Socialization } \\
\text { of } \\
\text { community } \\
\text { participation in } \\
\text { maintaining public } \\
\text { facilities }\end{array}$ \\
\hline
\end{tabular}


Based on the analysis conducted above, the development strategies that can be carried out for the development of natural resources as new renewable energy for solar power include:

1. Optimizing the area of the sun-exposed area for solar panellocations

2. The use of solar panels on a small scale, for example PJU

3. Inviting the public to use renewable energy in the form ofsolar panels to meet their daily energy needs

4. Socialization of community participation in maintainingpublic facilities

\section{CONCLUSION}

Data analysis in order to produce optimal analysis validation in the process of preparing development programs potential development of new and renewable natural resources in Ngawi District, Ngawi Regency includes the developmentof hydro, solar, bioethanol and biogas energy sources.

\section{ACKNOWLEDGMENT}

This research is the result of a collaboration between the Regional Secretariat of Ngawi Regency with the Faculty of Social Sciences and Law regarding the preparation of Data Documents for Potential Natural Resources in the Development of New Renewable Energy in Ngawi Regency.

\section{REFERENCES}

[1] Y. R. Pasalli and A. B. Rehiara, "Design Planning of Micro-hydro Power Plant in Hink River," Procedia Environ. Sci., vol. 20, pp. 55-63, 2014.

[2] M. Munguia, "Renewable Energy Investment in Chile: Make Hay while the Sun Shines," Renew. Energy Focus, vol. 17, no. 6, pp. 234-236, 2016.

[3] A. C. Ferreira, J. Silva, S. Teixeira, J. C. Teixeira, and $\mathrm{S}$.

A. Nebra, "Assessment of the Stirling Engine Performance Comparing Two Renewable Energy Sources: Solar Energy and Biomass," Renew. Energy, vol. 154, 2020.

[4] P. Bórawski, A. Bełdycka-Bórawska, E. J. Szymańska,

K. J. Jankowski, B. Dubis, and J. W. Dunn, "Development of Renewable Energy Sources Market and Biofuels in the European Union," J. Clean. Prod., vol. 228, pp. 467-484, 2019.

[5] E. S. Shuba and D. Kifle, "Microalgae to Biofuels:

„Promisinge alternative and renewable energy, review," Renew. Sustain. Energy Rev., vol. 81, no. April 2016, pp.743-755, 2018.

[6] D. Chiaramonti and T. Goumas, "Impacts on industrial- scale market deployment of advanced biofuels and recycled carbon fuels from the EU Renewable Energy Directive II," Appl. Energy, vol. 251, no. May 2019, p. 113351, 2019.

[7] F. D. Mayer, M. Brondani, M. C. Vasquez Carrillo, R. Hoffmann, and E. E. Silva Lora, "Revisiting Energy Efficiency, Renewability, and Sustainability Indicators in Biofuels Life Cycle: Analysis and Standardization Proposal," J. Clean. Prod., vol. 252, 2020.

[8] A. D. Korberg, I. R. Skov, and B. V. Mathiesen, "The Role of Biogas and Biogas-derived Fuels in a $100 \%$ Renewable Energy System in Denmark," Energy, p. 117426, 2020. 